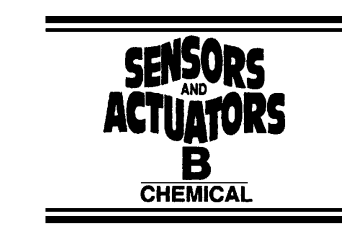

www.elsevier.com/locate/snb

\title{
Gas-sensitive properties of thin and thick film sensors based on $\mathrm{Fe}_{2} \mathrm{O}_{3}-\mathrm{SnO}_{2}$ nanocomposites
}

\author{
D. Kotsikau ${ }^{\mathrm{a}, *}$, M. Ivanovskaya ${ }^{\mathrm{a}}$, D. Orlik ${ }^{\mathrm{a}}$, M. Falasconi ${ }^{\mathrm{b}}$ \\ ${ }^{a}$ Scientific Research Institute for Physical and Chemical Problems, Belarus State University, Leningradskaya 14, 220050 Minsk, Belarus \\ b INFM-Gas Sensor Laboratory, University of Brescia, Via Valotti 9, 25133 Brescia, Italy \\ Received 15 December 2003; received in revised form 10 February 2004; accepted 18 February 2004
}

\begin{abstract}
Influence of phase composition, structural peculiarities and grain size of $\mathrm{Fe}_{2} \mathrm{O}_{3}-\mathrm{SnO}_{2}$ nanocomposites prepared by sol-gel technology on gas-sensitive properties of the corresponding gas sensors has been studied in the paper. The characteristics of thin film sensors were obtained with regards to $\mathrm{NO}_{2}$ and $\mathrm{C}_{2} \mathrm{H}_{5} \mathrm{OH}$. Behaviour of thick film sensors was estimated in humid $\mathrm{C}_{2} \mathrm{H}_{5} \mathrm{OH}$ ambient. High sensitivity of $\mathrm{Fe}_{2} \mathrm{O}_{3}-\mathrm{SnO}_{2}$ samples containing highly dispersive $\mathrm{Fe}_{2} \mathrm{O}_{3}$ phase has been revealed. The composites consisting of poorly crystallised $\alpha-\mathrm{Fe}_{2} \mathrm{O}_{3}$ along with $\mathrm{Sn}(\mathrm{IV})-\alpha-\mathrm{Fe}_{2} \mathrm{O}_{3}$ solid solution demonstrate maximum sensitivity to ethanol. Structural and functional distinctions of the $\mathrm{Fe}_{2} \mathrm{O}_{3}-\mathrm{SnO}_{2}$ composites obtained by using different $\mathrm{Fe}$-precursors $\left(\mathrm{Fe}^{3+}\right.$ and $\mathrm{Fe}^{2+}$ inorganic salts) have been revealed. Mechanisms of the processes, which determine gas-sensitive behaviour of the composites, are considered.

(C) 2004 Published by Elsevier B.V.
\end{abstract}

Keywords: $\mathrm{Fe}_{2} \mathrm{O}_{3}-\mathrm{SnO}_{2}$ nanocomposites; Structural characteristics; Gas sensitivity

\section{Introduction}

$\mathrm{SnO}_{2}$-based composites are commonly used materials for gas sensing application. Simple $\mathrm{SnO}_{2}$ is characterised by low sensitivity and unsuitable selectivity to most of toxic and explosive gases [1-3]. This objective causes the necessity of $\mathrm{SnO}_{2}$ modifying by various additives like noble metals (Pd, Pt, $\mathrm{Au}$ ) [4] and metal ions of variable valency (Mo, Ni, Fe, Sb). One of the most prospective ways to achieve good sensor performance is the obtaining sensitive layers of complex composition, where the functions of receptor and transducer are divided between different phases [5]. As it has been established by Yamazoe [6], metal cations, which are characterised by electronegativity lower than electronegativity of $\mathrm{Sn}(\mathrm{IV})$, increase the sensitivity of $\mathrm{SnO}_{2}$-based sensors to ethanol.

The analysis of the existing literature shows that the layers based on the $\mathrm{Fe}_{2} \mathrm{O}_{3}-\mathrm{SnO}_{2}$ composites possess high sensitivity to ethanol and suitable response to $\mathrm{NO}_{2}, \mathrm{CO}$ and $\mathrm{CH}_{4}$.

Tan et al. [7] reported good ethanol sensitivity values of $\mathrm{Fe}_{2} \mathrm{O}_{3}-\mathrm{SnO}_{2}$ thick film as high as 850 at 1000 ppm in air.

\footnotetext{
* Corresponding author. Tel.: +375-17-220-81-06; fax: +375-17-226-46-96; mobile: +375-296808106. E-mail address: kotsikau@bsu. by (D. Kotsikau).
}

The sensor is selective to ethanol over carbon monoxide and hydrogen. The functional parameters are also found to be very stable.

The introduction of $\mathrm{Fe}$ in $\mathrm{SnO}_{2}$ thin films by means of RGTO technique leads to the formation of the new ternary compound $\mathrm{Sn}_{x} \mathrm{Fe}_{1-x} \mathrm{O}_{y}$, which shows high response to $\mathrm{CO}$ [8]. Maximum sensitivity (3. 2 for $500 \mathrm{ppm}$ ) was observed for Fe content of $1.8 \%$.

Suitable low-temperature detection of $\mathrm{CH}_{4}$ by $\alpha-\mathrm{Fe}_{2} \mathrm{O}_{3}$ $\left(\mathrm{SO}_{4}{ }^{2-}, \mathrm{Sn}\right)$ thick films as compared to other metal oxides was achieved by Chung and Lee [9]. As it was found, $\alpha-\mathrm{Fe}_{2} \mathrm{O}_{3}\left(\mathrm{SO}_{4}{ }^{2-}, \mathrm{Sn}\right)$ powders precipitated at different $\mathrm{pH}$ values exhibited different microstructures.

Remarkably, that structural peculiarities of oxide materials such as phase composition, dispersity and morphology, influence strongly the functional features (sensitivity, selectivity, long-term stability) of the corresponding gas sensors $[1,10]$. Moreover, type of sensitive layer (ceramic, thin film, thick film) determines substantially a sensor performance as well. But the fine structural features of an oxide system and its activity in reduction-oxidation reactions are not commonly taking into consideration.

This paper reports an investigation on structural and functional features of the $\mathrm{Fe}_{2} \mathrm{O}_{3}-\mathrm{SnO}_{2}$ composites prepared by different variations of the sol-gel technology. An attempt to establish correlation between the fine structural peculiarities 
of the complex oxide systems and their gas-sensitive properties regarding $\mathrm{NO}_{2}$ and $\mathrm{C}_{2} \mathrm{H}_{5} \mathrm{OH}$ has been made.

\section{Experimental}

Simple oxides/hydroxides of iron and tin were prepared by hydrolysis of the corresponding inorganic precursors by using base agent (aqueous solution of $\mathrm{NH}_{3}$ ). The precipitate then was washed thoroughly and transformed into colloidal solution (sol). The $\mathrm{Fe}_{2} \mathrm{O}_{3}-\mathrm{SnO}_{2}$ composites (Fe:Sn $=1: 9,1: 1,9: 1$ ) were formed by mixing iron and tin oxides/hydroxides in the required proportions followed by annealing of the dried species at different temperatures $\left(300,500,600,800^{\circ} \mathrm{C}\right)[5] . \mathrm{Fe}^{2+}$ precursors $\left(\mathrm{FeCl}_{2}, \mathrm{FeSO}_{4}\right)$ were used along with more common $\mathrm{Fe}^{3+}$ inorganic salts $\left(\mathrm{FeCl}_{3}, \mathrm{Fe}\left(\mathrm{NO}_{3}\right)_{3}, \mathrm{Fe}_{2}\left(\mathrm{SO}_{4}\right)_{3}\right.$. Using $\mathrm{Fe}^{3+}$ precursors leads to the formation of $\alpha-\mathrm{Fe}_{2} \mathrm{O}_{3}$ species; meanwhile, hydrolysis of $\mathrm{Fe}^{2+}$ salts under certain conditions allows to obtain metastable $\gamma$-modification of iron oxide [10]. Thus, two types of the composites were prepared: $\alpha-\mathrm{Fe}_{2} \mathrm{O}_{3}-\mathrm{SnO}_{2}$ (by mixing $\alpha-\mathrm{Fe}_{2} \mathrm{O}_{3}$ and $\mathrm{SnO}_{2}$ sols) and $\gamma-\mathrm{Fe}_{2} \mathrm{O}_{3}-\mathrm{SnO}_{2}$ (by mixing $\gamma-\mathrm{Fe}_{2} \mathrm{O}_{3}$ and $\mathrm{SnO}_{2}$ sols).

Structural investigations were carried out by XRD, EPR, TEM and Mössbauer spectroscopy.

The sensing layers were heated at $550{ }^{\circ} \mathrm{C}$ in air during $20 \mathrm{~h}$. High-temperature treatment provides measurable range of the layer resistance. Measurements of the temperature-dependent conductivity of the oxide layers were carried out in the region of temperature $100-500^{\circ} \mathrm{C}$ at RH 30\%. Gas-sensitive properties of thin film species were mostly studied regarding $1 \mathrm{ppm} \mathrm{NO}_{2}(\mathrm{RH} 40 \%)$. Thick film sensors were measured in humid ethanol vapours $(\mathrm{RH}$ $98 \%$ ) within the range $0.025-1.0 \%$ (0. $1 \%$ o corresponds to $45 \mathrm{mg} / \mathrm{m}^{3}$ of ethanol), thus modelling alcohol content in human's expirated air. A flow of gas was obtained by commercial ethanol generator GS-1 (Analitpribor, Kiev). The construction of the sensors is described elsewhere [11]. The sensor response was calculated as $\left(I_{\text {gas }}-I_{\text {air }}\right) / I_{\text {air }}$ at fixed $U$-value for thin films and as $\left(R_{\text {gas }}-R_{\text {air }}\right) / R_{\text {air }}$ in the case of thick film layers at detection of reducing gases and as $\left(I_{\text {air }}-I_{\text {gas }}\right) / I_{\text {gas }}$ and $\left(R_{\text {air }}-R_{\text {gas }}\right) / R_{\text {gas }}$ when detecting oxidising ambient, correspondingly; where $I_{\text {gas }}$ and $R_{\text {gas }}$ are current and layer conductivity in gas ambient; $I_{\text {air }}$ and $R_{\text {air }}$ are current and layer conductivity in air.

\section{Results and discussion}

The $\mathrm{Fe}_{2} \mathrm{O}_{3}-\mathrm{SnO}_{2}$ composites of the same $\mathrm{Fe}: \mathrm{Sn}$ ratio prepared via $\mathrm{Fe}^{2+}$ and $\mathrm{Fe}^{3+}$ precursors differ considerably regarding their phase composition (Fig. 1a and b ). The sharpest distinctions are observed when the samples been heated at temperatures below $500{ }^{\circ} \mathrm{C}$. It is important to note, that all the oxide systems mentioned in this paper are characterised by high system dispersity and relatively low de- gree of crystallinity (Table 1 ). The grain size of the samples annealed at $500{ }^{\circ} \mathrm{C}$ does not exceed $6 \mathrm{~nm}$.

The XRD reflections assigned to the $\alpha-\mathrm{Fe}_{2} \mathrm{O}_{3}-\mathrm{SnO}_{2}$ composites within the whole series of the applied component ratios (Fe:Sn $=9: 1,1: 1,1: 9)$ appear to be broad and low-intensive. This can be explained by very small size of $\mathrm{SnO}_{2}$ grains (about $2 \mathrm{~nm}$ ) and poor crystallinity of $\alpha-\mathrm{Fe}_{2} \mathrm{O}_{3}$ phase. The composites with Fe:Sn ratio 1:9 and 1:1 have the structure of $\mathrm{Fe}(\mathrm{III})-\mathrm{SnO}_{2}$ solid solution; in the case of the $\mathrm{Fe}_{2} \mathrm{O}_{3}-\mathrm{SnO}_{2}\left(\mathrm{Fe}: \mathrm{Sn}\right.$ 9:1), $\mathrm{Sn}(\mathrm{IV})-\alpha-\mathrm{Fe}_{2} \mathrm{O}_{3}$ solid solution is typical.

Fast removal of water and crystallisation of $\alpha-\mathrm{Fe}_{2} \mathrm{O}_{3}$ occur at temperatures above $500^{\circ} \mathrm{C}$ : the reflections of this phase become narrow. Noticeable $\mathrm{SnO}_{2}$ particle agglomeration accompanying the crystallisation processes was only observed at $800^{\circ} \mathrm{C}$. High-temperature treatment results in partial decomposition of the sample structure and isolation of simple oxide phases $-\mathrm{SnO}_{2}$ and $\alpha-\mathrm{Fe}_{2} \mathrm{O}_{3}$; the samples become heterogeneous.

As opposed to $\alpha-\mathrm{Fe}_{2} \mathrm{O}_{3}, \gamma-\mathrm{Fe}_{2} \mathrm{O}_{3}$ phase obtained by using the mentioned synthesis technique after drying at $150^{\circ} \mathrm{C}$ is characterised by rather well crystallinity and absence of constitutional water. However, annealing the sample based on metastable $\gamma-\mathrm{Fe}_{2} \mathrm{O}_{3}$ phase at $400-500{ }^{\circ} \mathrm{C}$ results in its transforming into $\alpha-\mathrm{Fe}_{2} \mathrm{O}_{3}$ one. Thus, the XRD patterns of both $\alpha-\mathrm{Fe}_{2} \mathrm{O}_{3}-\mathrm{SnO}_{2}$ and $\gamma-\mathrm{Fe}_{2} \mathrm{O}_{3}-\mathrm{SnO}_{2}$ species of the same component ratio become similar after heating at $800^{\circ} \mathrm{C}$. Besides, according to Mössbauer study, small areas of amorphous and highly dispersive $\mathrm{Fe}_{2} \mathrm{O}_{3}$ phase are also preserved within the $\alpha-\mathrm{Fe}_{2} \mathrm{O}_{3}-\mathrm{SnO}_{2}$ and $\gamma-\mathrm{Fe}_{2} \mathrm{O}_{3}-\mathrm{SnO}_{2}(\mathrm{Fe}: \mathrm{Sn}=$ 9:1, 1:1) samples up to $400{ }^{\circ} \mathrm{C}$. EPR and Mössbauer studies give evidence that the $\alpha-\mathrm{Fe}_{2} \mathrm{O}_{3}$ phase obtained through the amorphous $\mathrm{Fe}_{2} \mathrm{O}_{3}$ (via $\mathrm{Fe}^{3+}$ precursor) and by the thermally stimulated transformation of $\gamma-\mathrm{Fe}_{2} \mathrm{O}_{3}$ (via $\mathrm{Fe}^{2+}$ precursor) are significantly different: the motive of $\gamma-\mathrm{Fe}_{2} \mathrm{O}_{3}$ structure (cubic symmetry) preserves within the latter species [5]. This phenomenon is also typical of highly dispersive $\alpha$-modifications of iron oxides/hydroxides (trigonal symmetry). Note, that in the case of the $\gamma-\mathrm{Fe}_{2} \mathrm{O}_{3}-\mathrm{SnO}_{2}$ composites the grain size of both oxide phases $\left(\mathrm{Fe}_{2} \mathrm{O}_{3}\right.$ and $\left.\mathrm{SnO}_{2}\right)$ is greater as compared to the $\alpha-\mathrm{Fe}_{2} \mathrm{O}_{3}-\mathrm{SnO}_{2}$. This effect is typical of all series of component ratios and annealing temperatures. Consequently, one can expect that the samples based on $\gamma-\mathrm{Fe}_{2} \mathrm{O}_{3}$ and $\alpha-\mathrm{Fe}_{2} \mathrm{O}_{3}$ will demonstrate different gas-sensitive behaviour.

\subsection{Electrical measurements in air}

Electrical conductivity of the $\mathrm{Fe}_{2} \mathrm{O}_{3}-\mathrm{SnO}_{2}$ thin film layers with $\mathrm{Fe}: \mathrm{Sn}=1: 9$ and $1: 1$ is found to be considerably lower as compared to the $\mathrm{Fe}_{2} \mathrm{O}_{3}-\mathrm{SnO}_{2}(\mathrm{Fe}: \mathrm{Sn}=9: 1)$ composite and simple oxides in air (Fig. 2 ). The $\mathrm{Fe}_{2} \mathrm{O}_{3}-\mathrm{SnO}_{2}$ $(\mathrm{Fe}: \mathrm{Sn}=9: 1)$ and $\mathrm{SnO}_{2}$ demonstrate minimum resistance values. The conductivity of the $\mathrm{Fe}_{2} \mathrm{O}_{3}-\mathrm{SnO}_{2}(\mathrm{Fe}: \mathrm{Sn}=1: 9$, $1: 1)$ films is approximately equal at $100-500{ }^{\circ} \mathrm{C}$; however, the trends of the curves are quite dissimilar within the indi- 

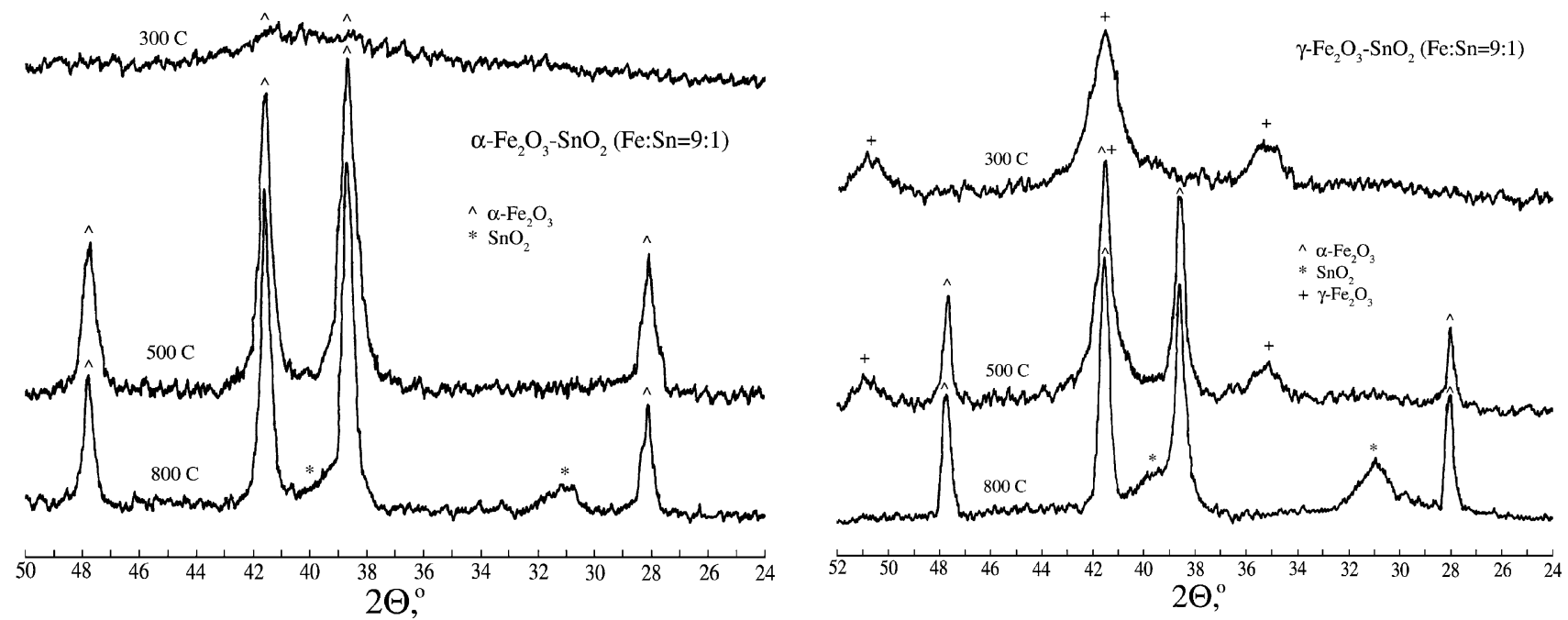

$\hat{\alpha} \alpha-\mathrm{Fe}_{2} \mathrm{O}_{3} \quad \alpha-\mathrm{Fe}_{2} \mathrm{O}_{3}-\mathrm{SnO}_{2}(\mathrm{Fe}: \mathrm{Sn}=1: 1)$
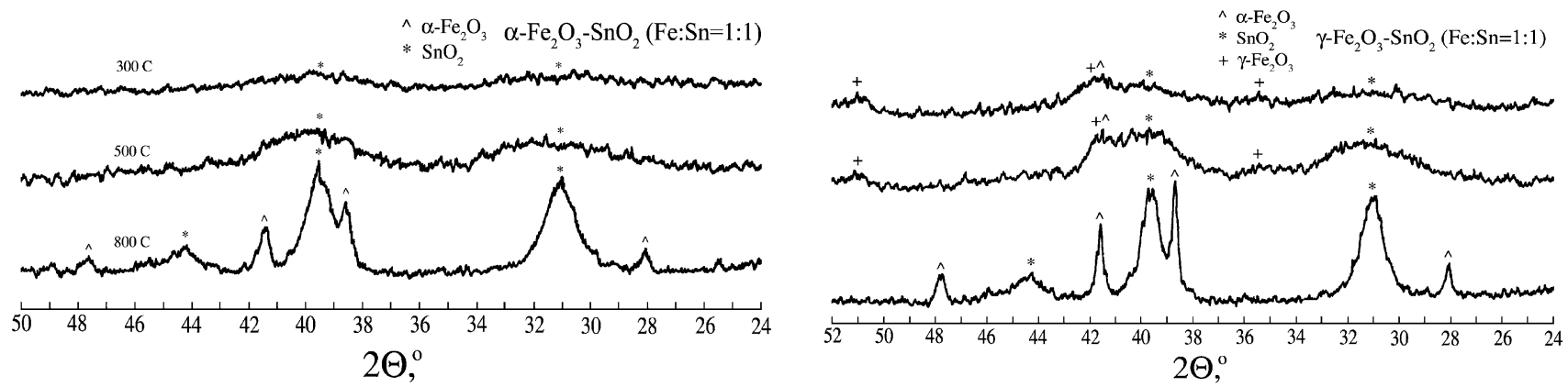

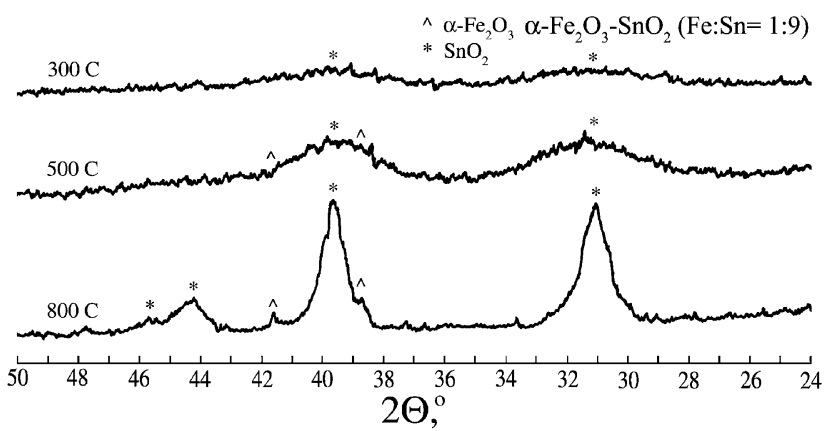

(a)

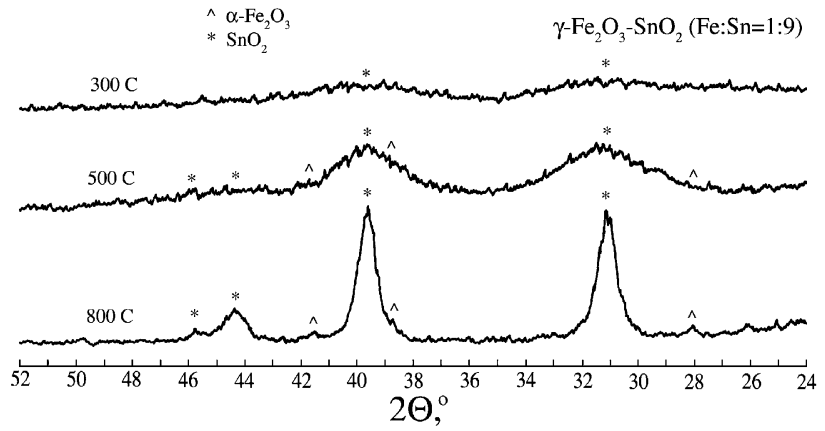

(b)

Fig. 1. XRD patterns of $\alpha-\mathrm{Fe}_{2} \mathrm{O}_{3}-\mathrm{SnO}_{2}$ (a) and $\gamma-\mathrm{Fe}_{2} \mathrm{O}_{3}-\mathrm{SnO}_{2}$ (b) composites (Fe:Sn = 9:1, 1:1, 1:9), annealed at different temperatures for $1 \mathrm{~h}$.

Table 1

Phase composition and grain size of simple $\mathrm{Fe}_{2} \mathrm{O}_{3}$ and $\mathrm{SnO}_{2}$ oxides and $\mathrm{Fe}_{2} \mathrm{O}_{3}-\mathrm{SnO}_{2}$ nanocomposites depending on annealing temperature

\begin{tabular}{|c|c|c|c|c|c|c|}
\hline \multirow[t]{2}{*}{$T\left({ }^{\circ} \mathrm{C}\right)$} & \multirow[t]{2}{*}{$\mathrm{SnO}_{2} d(\mathrm{~nm})$} & \multirow[t]{2}{*}{$\mathrm{Fe}_{2} \mathrm{O}_{3} d(\mathrm{~nm})$} & \multicolumn{2}{|c|}{$\alpha-\mathrm{Fe}_{2} \mathrm{O}_{3}-\mathrm{SnO}_{2}(\mathrm{Fe}: \mathrm{Sn}=1: 1)$} & \multicolumn{2}{|c|}{$\gamma-\mathrm{Fe}_{2} \mathrm{O}_{3}-\mathrm{SnO}_{2}(\mathrm{Fe}: \mathrm{Sn}=1: 1)$} \\
\hline & & & Phase & $d(\mathrm{~nm})$ & Phase & $d(\mathrm{~nm})$ \\
\hline 300 & 2 & - & $\begin{array}{l}\mathrm{SnO}_{2} \\
\alpha-\mathrm{Fe}_{2} \mathrm{O}_{3}\end{array}$ & $\begin{array}{l}2 \\
2\end{array}$ & $\begin{array}{l}\mathrm{SnO}_{2} \\
\gamma-\mathrm{Fe}_{2} \mathrm{O}_{3}\end{array}$ & $\begin{array}{l}2 \\
4\end{array}$ \\
\hline 500 & 6 & 15 & $\begin{array}{l}\mathrm{SnO}_{2} \\
\alpha-\mathrm{Fe}_{2} \mathrm{O}_{3}\end{array}$ & $\begin{array}{l}3 \\
3\end{array}$ & $\begin{array}{l}\mathrm{SnO}_{2} \\
(\alpha+\gamma)-\mathrm{Fe}_{2} \mathrm{O}_{3}\end{array}$ & $\begin{array}{l}5 \\
6\end{array}$ \\
\hline 800 & 40 & 70 & $\begin{array}{l}\mathrm{SnO}_{2} \\
\alpha-\mathrm{Fe}_{2} \mathrm{O}_{3}\end{array}$ & $\begin{array}{l}10 \\
30\end{array}$ & $\begin{array}{l}\mathrm{SnO}_{2} \\
\alpha-\mathrm{Fe}_{2} \mathrm{O}_{3}\end{array}$ & $\begin{array}{l}10 \\
45\end{array}$ \\
\hline
\end{tabular}




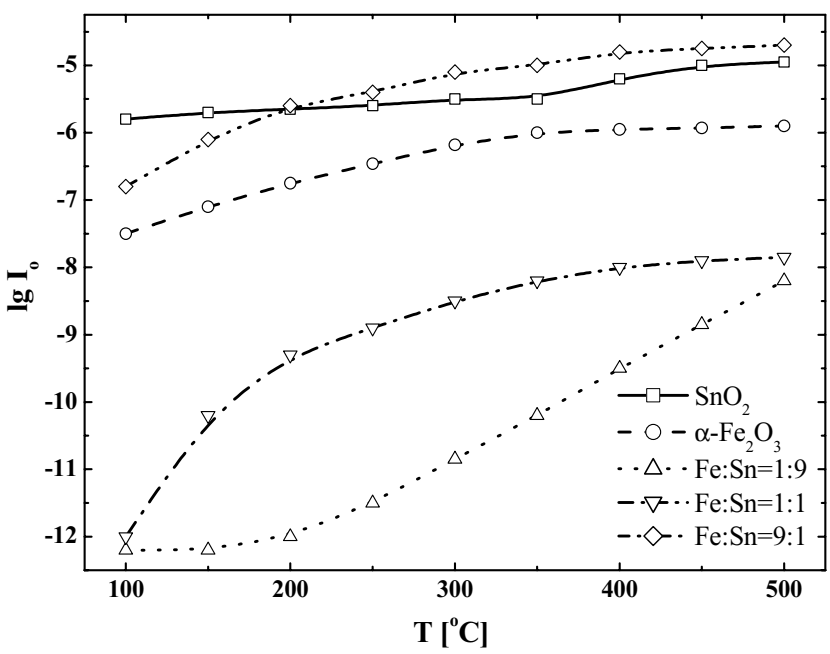

Fig. 2. Temperature-dependent conductivity of thin film simple oxides and $\alpha-\mathrm{Fe}_{2} \mathrm{O}_{3}-\mathrm{SnO}_{2}$ composites in air, $\mathrm{RH} 30 \%$.

cated temperature region. In the case of $\mathrm{Fe}: \mathrm{Sn}=1: 9$ the conductivity begins to rise gradually starting from $200^{\circ} \mathrm{C}$; the sample with equal content of the components demonstrates maximum conductivity change within a low-temperature region $\left(100-200^{\circ} \mathrm{C}\right)$. The conductivity of $\mathrm{SnO}_{2}$ is mainly determined by the presence of singly charged oxygen vacancies $\left(V_{\mathrm{o}}{ }^{-}\right)[12,13] . \mathrm{Fe}^{3+}$ ions, which occupy the $\mathrm{Sn}(\mathrm{IV})$ positions within $\mathrm{SnO}_{2}$ crystal lattice, are acting as electron acceptors; it results in decrease of charge carrier amount. Meanwhile, $\left[\mathrm{Fe}^{3+}-V_{\mathrm{o}}{ }^{-}\right]$associates are not participating in charge transfer. Temperature increase up to $400-550^{\circ} \mathrm{C}$ is an important requirement to provide electron activation and sufficient resistance drop. As it was noted above, the $\mathrm{Fe}_{2} \mathrm{O}_{3}-\mathrm{SnO}_{2}$ composites consist of highly dispersive oxide phases of iron and tin. The indicated phases are characterised by elevated activity and react readily under heating. $\mathrm{Sn}-\mathrm{OH}-\mathrm{Fe}$ and $\mathrm{Sn}-\mathrm{O}-\mathrm{Fe}$ bonding is possible at $\mathrm{SnO}_{2} / \mathrm{Fe}_{2} \mathrm{O}_{3}$ phase interface that leads to decreasing the contact resistance and increasing the potential barrier transmissivity.

Surface conductivity mainly contributes to the total conductivity of the thin oxide films at direct current measurements. The surface layer of amorphous $\mathrm{Fe}_{2} \mathrm{O}_{3}$ doped with $\mathrm{Sn}^{4+}$ ions provides an increased conductivity of the $\mathrm{Fe}_{2} \mathrm{O}_{3}-\mathrm{SnO}_{2}(\mathrm{Sn}: \mathrm{Fe}=1: 1)$ film as contrast to the $\mathrm{Fe}_{2} \mathrm{O}_{3}-\mathrm{SnO}_{2}$ (Fe:Sn = 1:9) [14,15]. Adding $\mathrm{SnO}_{2}$ to $\mathrm{Fe}_{2} \mathrm{O}_{3}$ brings to increasing the free charge carrier concentration, and consequently, to heightening the conductivity of the $\mathrm{Fe}_{2} \mathrm{O}_{3}-\mathrm{SnO}_{2}(\mathrm{Fe}: \mathrm{Sn}=9: 1)$ having the structure of $\mathrm{Sn}(\mathrm{IV})-\alpha-\mathrm{Fe}_{2} \mathrm{O}_{3}$ solid solution.

The thick film layers based on the $\mathrm{Fe}_{2} \mathrm{O}_{3}-\mathrm{SnO}_{2}$ composites and simple oxides demonstrate the same regularities that intrinsic to the corresponding thin films, but absolute conductivity values appear to be significantly lower in the case of the thick films (Fig. 3 ). It is probably explained by poor contact between separate particles of the powder. Because of the indicated point we were not able to perform the

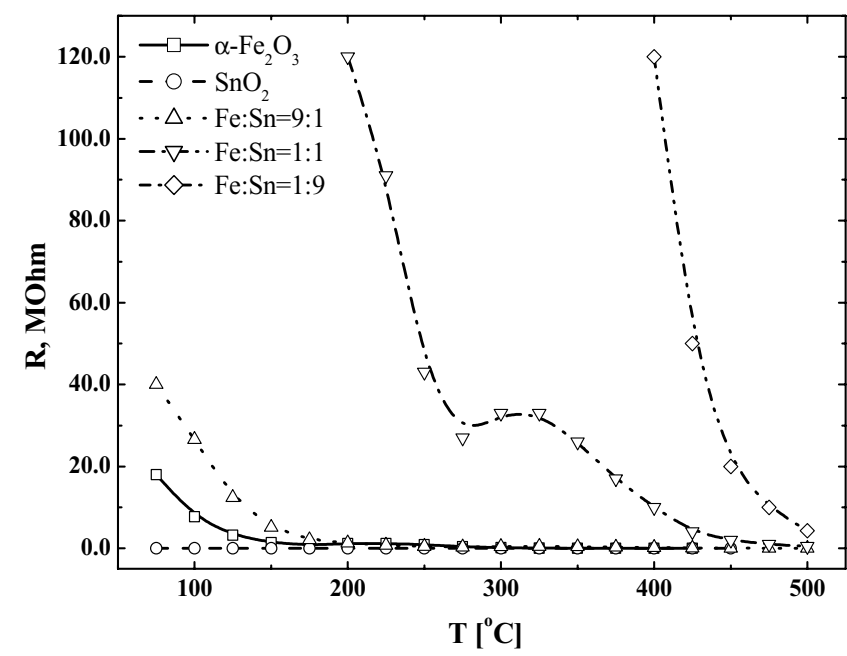

Fig. 3. Temperature-dependent resistance of thick film simple oxides and $\mathrm{Fe}_{2} \mathrm{O}_{3}-\mathrm{SnO}_{2}$ composites in air, $\mathrm{RH} 30 \%$.

functional characterisation of some samples at low operating temperatures in both air and gas ambient. The sample with Fe:Sn ratio 1:9 appeared to be of extremely high resistance in air.

\subsection{Electrical measurements in gas ambient}

Thin and thick $\mathrm{Fe}_{2} \mathrm{O}_{3}-\mathrm{SnO}_{2}$ films of different structure and chemical composition are characterised by dissimilar behaviour in gas ambient of different chemical nature-oxidising $\left(\mathrm{NO}_{2}\right)$ and reducing $\left(\mathrm{C}_{2} \mathrm{H}_{5} \mathrm{OH}\right)$ gases. Humid ethanol vapours (RH 98\%) were used that caused by great importance of control the alcohol concentration in human's expirations. It is obvious, that great humidity influences strongly the sensitive layer behaviour. As it was established by Kappler et al. [16], humidity growth leads to an increase in the number of oxygen vacancies that enhances the chemisorption of oxygen and forms specific oxygen sites. In synthetic air an increase of oxygen ions occurs at the sensor surface when humidity is increased. The rise in the number of available oxygen partners for ethanol in the oxidation reaction causes enhancement of the sensor signal.

The thin film sensors are found to be more suitable for detection of $\mathrm{NO}_{2}$; meanwhile, the thick films demonstrate good performance when detecting ethanol vapours. Note, that the response values $(\mathrm{d} G / G)$ to oxidising gases of all the sensors are very low as compared to individual oxides like $\mathrm{SnO}_{2}$ and $\operatorname{In}_{2} \mathrm{O}_{3}$. The response of the best material to $1 \mathrm{ppm}$ $\mathrm{NO}_{2}$ does not exceed $0.5 \mathrm{r}$. u. At lower $\mathrm{NO}_{2}$ concentration the signal is unstable and poorly reproducible (Fig. 4 ). The only $\alpha-\mathrm{Fe}_{2} \mathrm{O}_{3}-\mathrm{SnO}_{2}$ samples show measurable response values to $\mathrm{NO}_{2}$ among the thin film layers. The $\alpha-\mathrm{Fe}_{2} \mathrm{O}_{3}-\mathrm{SnO}_{2}$ $(\mathrm{Fe}: \mathrm{Sn}=1: 1)$ composite demonstrates maximum sensitivity at $100^{\circ} \mathrm{C}$. It is important, that $\mathrm{NO}_{2}$ molecules proceed as electron donors within low-temperature region. It can be connected with the point that the conductivity of 


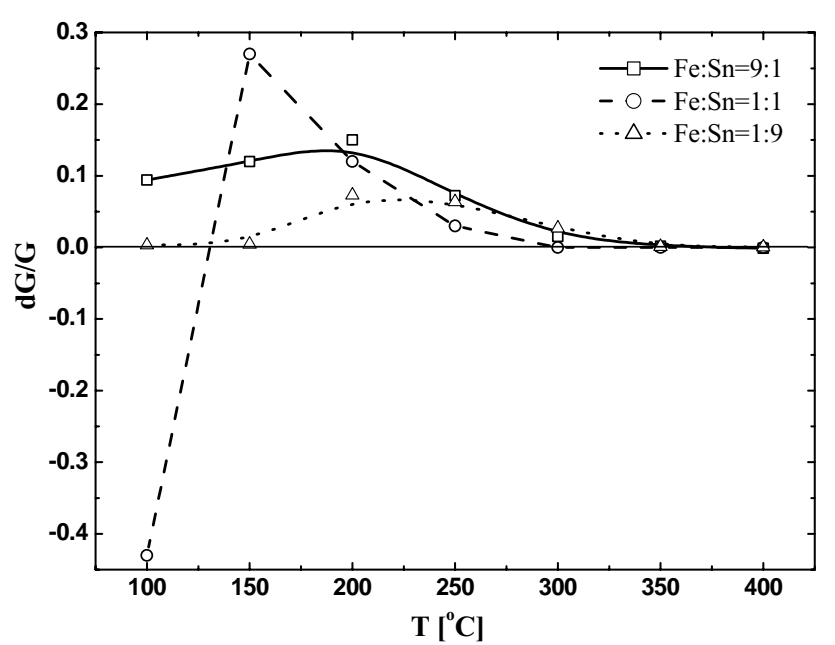

Fig. 4. Temperature dependent response of $\mathrm{Fe}_{2} \mathrm{O}_{3}-\mathrm{SnO}_{2}$ thin film sensors to $1 \mathrm{ppm} \mathrm{NO}_{2}, \mathrm{RH} 40 \%$.

the $\mathrm{Fe}_{2} \mathrm{O}_{3}-\mathrm{SnO}_{2}$ composites (up to $150^{\circ} \mathrm{C}$ ) is determined by the presence of surface $\mathrm{OH}$-groups, which desorbs at $150-400{ }^{\circ} \mathrm{C}$. Besides, the response of the $\alpha-\mathrm{Fe}_{2} \mathrm{O}_{3}-\mathrm{SnO}_{2}$ sensors of all series of compositions to $\mathrm{NO}_{2}$ reaches its maximum value at temperatures, at which maximum layer conductivity drop in air is observed.

In the case of thick films, the $\alpha-\mathrm{Fe}_{2} \mathrm{O}_{3}-\mathrm{SnO}_{2}$ and $\gamma-\mathrm{Fe}_{2} \mathrm{O}_{3}-\mathrm{SnO}_{2}$ (Fe:Sn = 9:1) composites show maximum sensitivity to humid $\mathrm{C}_{2} \mathrm{H}_{5} \mathrm{OH}$ vapours. As it was noted above, the layers were annealed at $550{ }^{\circ} \mathrm{C}$ in order to provide measurable sensor conductivity. Thus prepared samples have the structure of $\mathrm{Sn}(\mathrm{IV})-\alpha-\mathrm{Fe}_{2} \mathrm{O}_{3}$ solid solution, $\gamma-\mathrm{Fe}_{2} \mathrm{O}_{3}$ transforms completely into $\alpha-\mathrm{Fe}_{2} \mathrm{O}_{3}$. However, certain insignificant differences are observed in the $\alpha-\mathrm{Fe}_{2} \mathrm{O}_{3}-\mathrm{SnO}_{2}$ and $\gamma-\mathrm{Fe}_{2} \mathrm{O}_{3}-\mathrm{SnO}_{2}$ behaviour that can be caused by certain distinctions in grain size and microstructure of the samples. Thus, the composites obtained via $\mathrm{Fe}^{3+}$ precursor $\left(\alpha-\mathrm{Fe}_{2} \mathrm{O}_{3}-\mathrm{SnO}_{2}\right)$ are characterised by higher response and increased optimal detecting temperature (Fig. 5 ).

Maximum response to ethanol of the $\mathrm{Fe}_{2} \mathrm{O}_{3}-\mathrm{SnO}_{2}$ $(\mathrm{Fe}: \mathrm{Sn}=9: 1,1: 1)$ layer appears to be greater than that one demonstrated by simple oxides $\left(\mathrm{SnO}_{2}, \mathrm{Fe}_{2} \mathrm{O}_{3}\right)$ (Fig. 6 ). We failed to measure the $\mathrm{Fe}_{2} \mathrm{O}_{3}-\mathrm{SnO}_{2}(\mathrm{Fe}: \mathrm{Sn}=1: 9)$ sensor because of its extremely high resistance. Remarkably, that the optimal operating temperatures of the whole series of the thick film sensors lie in narrow-temperature range $\left(280-320^{\circ} \mathrm{C}\right)$.

The dependence of the thick film sensor resistance vs. concentration of humid ethanol vapour $\left(270^{\circ} \mathrm{C}\right)$ is presented in Fig. 7 . There is a clear difference in the behaviour of the $\alpha-\mathrm{Fe}_{2} \mathrm{O}_{3}-\mathrm{SnO}_{2}$ and $\gamma-\mathrm{Fe}_{2} \mathrm{O}_{3}-\mathrm{SnO}_{2}$ species. The $\alpha-\mathrm{Fe}_{2} \mathrm{O}_{3}-\mathrm{SnO}_{2}$ layers demonstrate suitable performance when detecting alcohol within the concentration range $0.05-1.0 \%$. In contrast, the $\gamma-\mathrm{Fe}_{2} \mathrm{O}_{3}-\mathrm{SnO}_{2}$ composites and simple oxides are characterised by unsuitably

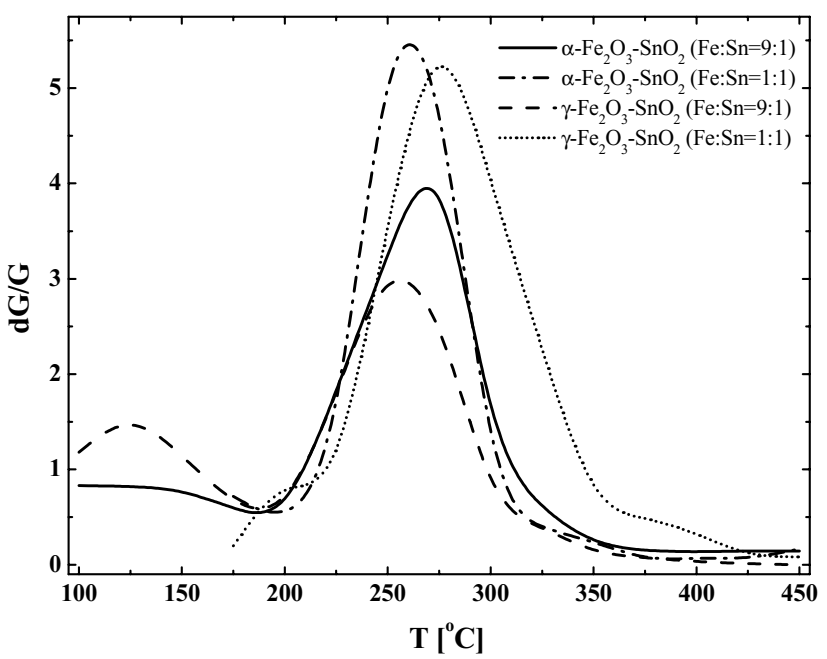

Fig. 5. Temperature-dependent response of $\alpha-\mathrm{Fe}_{2} \mathrm{O}_{3}-\mathrm{SnO}_{2}$ and $\gamma-\mathrm{Fe}_{2} \mathrm{O}_{3}-$ $\mathrm{SnO}_{2}$ thick film sensors to $0.05 \%$ of $\mathrm{C}_{2} \mathrm{H}_{5} \mathrm{OH}$.

low $\Delta R_{\text {layer }} / \Delta C_{\text {gas }}$ ratio that makes the mentioned materials $\quad 277$ unusable for accurate registration of the gas concentration. $\quad 278$

According to the available EPR data, two types of Fe(III) 279 centres occur within the $\mathrm{Fe}_{2} \mathrm{O}_{3}-\mathrm{SnO}_{2}$ composites obtained 280 both via $\mathrm{Fe}^{3+}$ and $\mathrm{Fe}^{2+}$ precursors (Fig. 8 ): (I) $g=4.3, \quad 281$ $\Delta B=4 \mathrm{mT}$ and (II) $g=4.3, \Delta B=4 \mathrm{mT}$. The signal I, 282 which is observed in the case of $\mathrm{SnO}_{2}$ doped with $\mathrm{Fe}^{3+}{ }_{283}$ ions is assigned to isolated Fe(III) centres in strong crystal 284 field of rhombic symmetry [17]. Strong crystal field can be 285 caused by the distribution of Fe(III) ions within near-surface 286 layers of $\mathrm{SnO}_{2}$, as well as by the presence of oxygen va- 287 cancies in close environment of $\mathrm{Fe}(\mathrm{III})$ within $\mathrm{SnO}_{2}$ matrix 288 [18]. Both intensity and shape of the signal II $(g \sim 2.0)$ de- 289 pend on the recording temperature. The spectrum recorded 290 at $77 \mathrm{~K}$ allows realising that the broadened resonance sig- 291 nal II contains two lines at $g \sim 2.3$ and $\sim 2$. 0 . The former 292

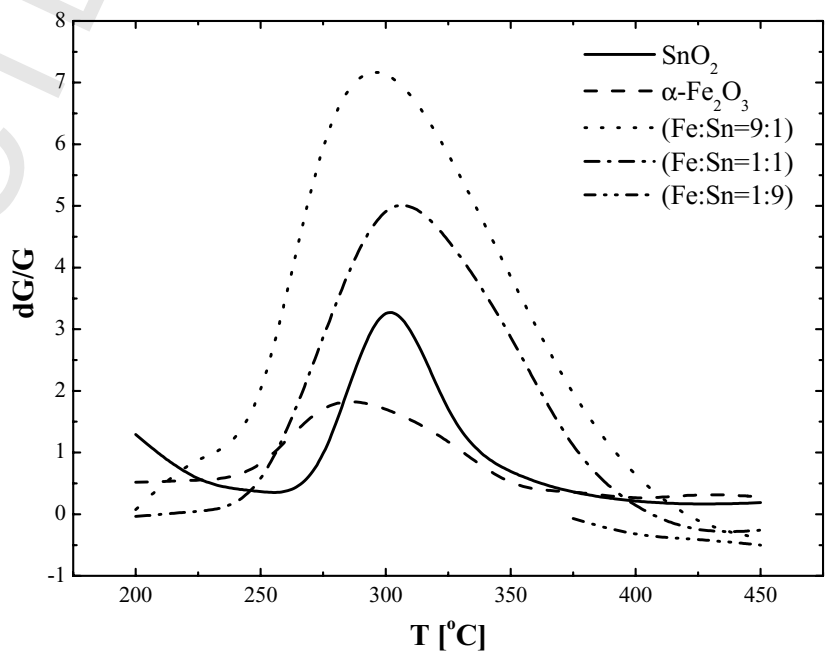

Fig. 6. Temperature-dependent response of thick film sensors based on simple oxides and $\alpha-\mathrm{Fe}_{2} \mathrm{O}_{3}-\mathrm{SnO}_{2}$ composites to 0 . $05 \%$ of $\mathrm{C}_{2} \mathrm{H}_{5} \mathrm{OH}$. 


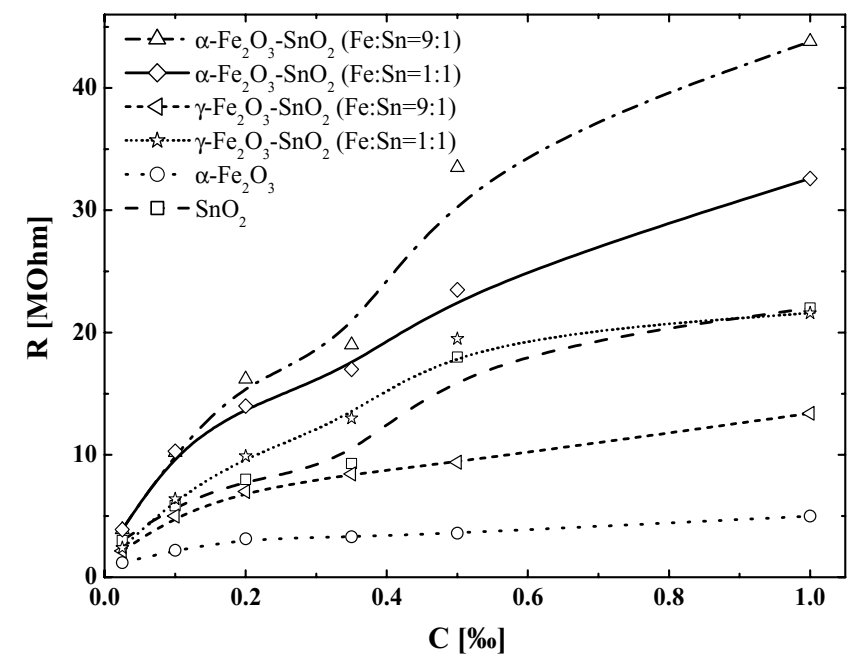

Fig. 7. Concentration-dependent resistance of thick film sensors in humid ( $\mathrm{RH} 98 \%) \mathrm{C}_{2} \mathrm{H}_{5} \mathrm{OH}$ ambient. Operating temperature $275^{\circ} \mathrm{C}$.

line is assigned to noncrystalline $\mathrm{Fe}_{2} \mathrm{O}_{3}$ nanoparticles, which consist of $\mathrm{Fe}(\mathrm{III})$ ions in cubic symmetry of oxygen close environment. Note, that the mentioned environment is similar to a greater extent to $\gamma-\mathrm{Fe}_{2} \mathrm{O}_{3} / \gamma$ - $\mathrm{FeOOH}$ crystal structure (cubic symmetry) rather than to trigonal $\alpha-\mathrm{Fe}_{2} \mathrm{O}_{3}$. The second component of the signal II $(g \sim 2.0)$ is assigned to the associates of $\mathrm{Fe}$ (III) ions; it is typical of superparamagnetic $\mathrm{Fe}_{2} \mathrm{O}_{3}$ clusters. This fact explains activity of the studied species in gas adsorption processes. Thus, gas-sensitive and electro-physical properties of the thin and thick film $\mathrm{Fe}_{2} \mathrm{O}_{3}-\mathrm{SnO}_{2}$ are substantially determined by $\mathrm{Fe}(\mathrm{III})$ state.

Treating the $\mathrm{Fe}_{2} \mathrm{O}_{3}-\mathrm{SnO}_{2}(\mathrm{Fe}: \mathrm{Sn}=1: 1)$ powder with $\mathrm{NO}_{2}\left(120^{\circ} \mathrm{C}, 10 \mathrm{~min}\right)$ leads to the increase of the signal II only; the signal I remains unchanged. This fact gives evidence that only amorphous $\mathrm{Fe}_{2} \mathrm{O}_{3}$ can participate in $\mathrm{NO}_{2}$ adsorption; the isolated $\mathrm{Fe}(\mathrm{III})$ ions within $\mathrm{SnO}_{2}$ lat-

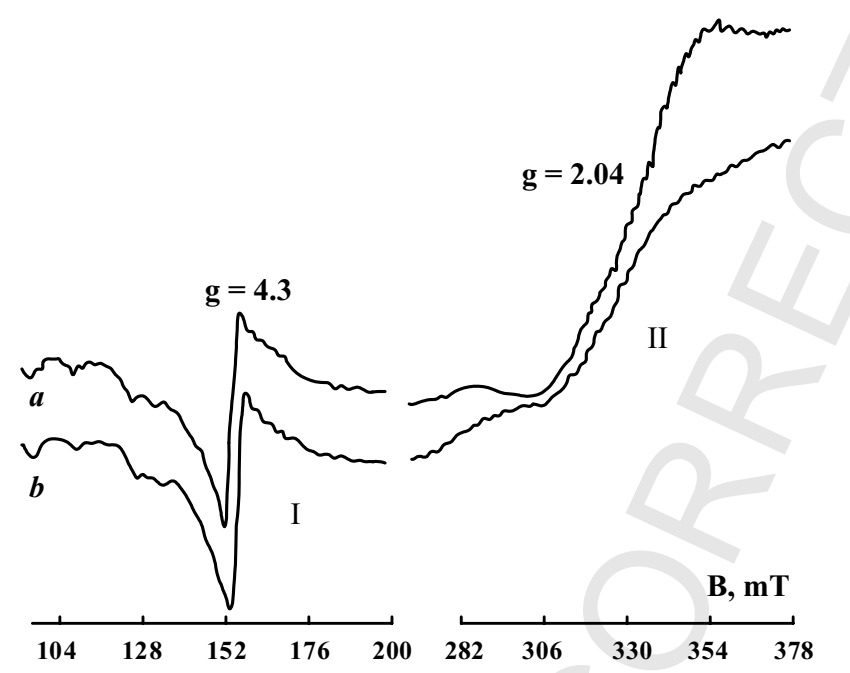

Fig. 8. EPR spectrum of $\mathrm{Fe}_{2} \mathrm{O}_{3}-\mathrm{SnO}_{2}(\mathrm{Fe}: \mathrm{Sn}=1: 1)$ powder: (a) initial; (b) treated with $\mathrm{NO}_{2}\left(10 \mathrm{~min}, 130^{\circ} \mathrm{C}\right)$.

Table 2

Parameters of ${ }^{57} \mathrm{Fe}$ Mössbauer spectra of $\mathrm{Fe}_{2} \mathrm{O}_{3}$ and $\mathrm{Fe}_{2} \mathrm{O}_{3}-\mathrm{SnO}_{2}$ composite

\begin{tabular}{llll}
\hline Sample & $\delta(\mathrm{mm} / \mathrm{s})$ & $\Delta(\mathrm{mm} / \mathrm{s})$ & $B(\mathrm{~T})$ \\
\hline $\begin{array}{l}\mathrm{Fe}_{2} \mathrm{O}_{3}-\mathrm{SnO}_{2} \\
\quad(\mathrm{Fe}: \mathrm{Sn} 1: 1), 300^{\circ} \mathrm{C}\end{array}$ & $0.35 \pm 0.02$ & $0.72 \pm 0.02$ & 50.8 \\
$\mathrm{Fe}_{2} \mathrm{O}_{3}-\mathrm{SnO}_{2}$ & $0.35 \pm 0.02$ & $0.87 \pm 0.02$ & 50.8 \\
$\quad(\mathrm{Fe}: \mathrm{Sn} 1: 1), 500^{\circ} \mathrm{C}$ & & & \\
$\gamma-\mathrm{Fe}_{2} \mathrm{O}_{3}$ (bulk) & $0.34 \pm 0.01$ & $-0.053 \pm 0.020$ & 49.6 \\
$\alpha-\mathrm{Fe}_{2} \mathrm{O}_{3}$ (bulk) & $0.47 \pm 0.03$ & $0.23 \pm 0.01$ & 51.8 \\
$\mathrm{Fe}_{2} \mathrm{O}_{3}$ (amorphous) & $0.39 \pm 0.02$ & $0.09 \pm 0.01$ & 50.7 \\
\hline
\end{tabular}

Recorded at $300 \mathrm{~K}$.

tice are inactive. This explains greater sensitivity of the 309 $\mathrm{Fe}_{2} \mathrm{O}_{3}-\mathrm{SnO}_{2}$ (Fe:Sn = 1:1 and 9:1) films to $\mathrm{NO}_{2}$ as com- 310 pared to $\mathrm{Fe}_{2} \mathrm{O}_{3}-\mathrm{SnO}_{2}(\mathrm{Fe}: \mathrm{Sn}=1: 9)$.

Mössbauer spectra of the $\alpha-\mathrm{Fe}_{2} \mathrm{O}_{3}-\mathrm{SnO}_{2}$ and $\gamma-\mathrm{Fe}_{2} \mathrm{O}_{3}-$ $\mathrm{SnO}_{2}$ samples (annealing temperature $300-500^{\circ} \mathrm{C}$ ) represent a broadened doublet, which is an evidence of superparamagnetic $\mathrm{Fe}_{2} \mathrm{O}_{3}$ particles $(d \sim 3-4 \mathrm{~nm}$ ) formation. Thus, the samples with $\mathrm{Fe}: \mathrm{Sn}=9: 1$ and 1:1 contain areas of highly dispersive and poorly crystallised $\mathrm{Fe}_{2} \mathrm{O}_{3}$. The parameters of the $\mathrm{Fe}_{2} \mathrm{O}_{3}-\mathrm{SnO}_{2}$ spectra are different from the parameters, which are typical of the spectra of both $\alpha-\mathrm{Fe}_{2} \mathrm{O}_{3}$ and $\gamma-\mathrm{Fe}_{2} \mathrm{O}_{3}$ bulk phases. However, the values of isomeric shift $(\delta)$ and induction of magnetic field $(B)$ of amorphous $\mathrm{Fe}_{2} \mathrm{O}_{3}$ are closer to the parameters of cubic $\gamma-\mathrm{Fe}_{2} \mathrm{O}_{3}$ rather than to trigonal $\alpha-\mathrm{Fe}_{2} \mathrm{O}_{3}$ that is in agreement with the EPR data (Table 2 ). The coordination of $\mathrm{Fe}(\mathrm{III})$, which is specific of cubic structure of unit cell $\left(\gamma-\mathrm{FeOOH}, \gamma-\mathrm{Fe}_{2} \mathrm{O}_{3}\right)$, preserves within the $\mathrm{Fe}_{2} \mathrm{O}_{3}$ amorphous phase. Considerable increase of the quadrupole splitting $(\Delta)$ values as compared to the simple oxides is typical of the studied composites; it indicates that the crystal environment of $\mathrm{Fe}$ (III) points within the $\mathrm{Fe}_{2} \mathrm{O}_{3}$ matrix is strongly irregular in the presence of $\mathrm{Sn}(\mathrm{IV})$.

Two ways of alcohol (in particular, ethanol) molecule conversion are possible at oxide surface-dehydrogenation (1) and dehydration (2) $[6,19]$ :

$$
\begin{aligned}
& \mathrm{CH}_{3} \mathrm{CH}_{2} \mathrm{OH} \rightarrow \mathrm{CH}_{3} \mathrm{CHO}+\frac{1}{2} \mathrm{H}_{2} \quad \text { (dehydrogenation) } \\
& \mathrm{CH}_{3} \mathrm{CH}_{2} \mathrm{OH} \rightarrow \mathrm{C}_{2} \mathrm{H}_{4}+\mathrm{H}_{2} \mathrm{O} \quad \text { (dehydration) }
\end{aligned}
$$

Besides, further oxidation of the formed products (fore- 336 most, oxidation of $\mathrm{H}$ atoms) is also possible; it should result 337 in sensor response growth. Thus, the process (1) most of- 338 ten proceeds through the oxidising dehydrogenation mech- 339 anism:

$$
\begin{gathered}
\mathrm{CH}_{3} \mathrm{CH}_{2} \mathrm{OH} \stackrel{\mathrm{O}^{2-}, \mathrm{O}^{-}}{\longrightarrow} \mathrm{CH}_{3} \mathrm{CHO}+\mathrm{H}_{2} \mathrm{O} \\
\text { (oxidising dehydrogenation) }
\end{gathered}
$$

As we established earlier [11], lattice oxygen is only 344 participating in the indicated process at high operating 345 temperatures $\left(300-400{ }^{\circ} \mathrm{C}\right)$. The role of adsorbed oxygen 346 consists of regenerating of partially reduced oxide surface. 347 
The oxidising dehydrogenation is heterolytic catalytic reaction. The process involves both reductive-oxidative and acid-base steps. In particular, alcohol molecule adsorption at metal cations, which play role of Lewis centres, is related to acid-base reaction. The reactivity of oxides in acid-base reactions depends on the electronegativity of cations $\mathrm{M}^{n+}$ :

$\chi=\chi_{\mathrm{o}}(2 n+1)$

where $\chi_{0}$ is the Pauling's electronegativity, $n$ the ion charge. The electronegativity can be used as the measure of Lewis acid activity [20]. Adsorption of alcohol molecules at Lewis sites is going with great output. The relative measure of an oxide activity in the oxidation reactions can be oxygen-oxide surface bonding energy. Lesser energies of oxygen atom isolation from an oxide surface favour higher oxide oxidising ability. Complete oxidation of the intermediate products is possible at the surface of the oxide, which is characterised by small values of $\mathrm{M}-\mathrm{O}$ bonding energy and electronegativity. Thus, due to the low $\mathrm{Fe}-\mathrm{O}$ bonding energy and increased basicity of $\mathrm{Fe}_{2} \mathrm{O}_{3}$ in comparison to $\mathrm{SnO}_{2}\left(E_{\mathrm{Fe}-\mathrm{O}}=56, E_{\mathrm{Sn}-\mathrm{O}}=70 \mathrm{kcal} / \mathrm{g}\right.$ per atom; $\left.\chi\left(\mathrm{Fe}^{2+}\right)=13.72, \chi\left(\mathrm{Sn}^{4+}\right)=17.64\right) \mathrm{Fe}(\mathrm{III})$ centres promote further oxidation of intermediate products of ethanol molecule transformation [21]. For the detailed mechanism of ethanol detection refer to [22].

Thus, substitution of $\mathrm{Sn}(\mathrm{IV})$ for the isolated Fe(III) ions in points of $\mathrm{SnO}_{2}$ lattice decreases considerably electrical conductivity of $\mathrm{SnO}_{2}$ films and their sensitivity to both oxidising $\left(\mathrm{NO}_{2}\right)$ and reducing $\left(\mathrm{C}_{2} \mathrm{H}_{5} \mathrm{OH}\right)$ gases. As it was noted above, the $\mathrm{Fe}_{2} \mathrm{O}_{3}-\mathrm{SnO}_{2}$ nanocomposites, which have a structure of $\mathrm{Sn}(\mathrm{IV})-\alpha-\mathrm{Fe}_{2} \mathrm{O}_{3}$ solid solution, show high response to ethanol vapours due to the presence of two types of adsorption centres-Sn(IV) and Fe(III). The two centres are characterised by different activity in the course of both reduction-oxidation and acid-base reactions.

Moreover, high dispersity of $\mathrm{Sn}(\mathrm{IV})-\alpha-\mathrm{Fe}_{2} \mathrm{O}_{3}$ solid solution provides efficient electron exchange between the cations: $\mathrm{Fe}(\mathrm{III}) \leftrightarrow \mathrm{Fe}(\mathrm{II})$. All this produces greater conductivity drop of the active layer and, consequently, improves the sensor performance.

\section{Conclusion}

Sol-gel technology provides the obtaining of complex oxide systems, which differ by chemical composition (oxide nature, component ratio), structure (phase composition, peculiarities of microstructure) and dispersity.

As it was found out, the studied composites are characterised by distinct electrical properties in both air and gas ambient. Besides, type of the used sensors (thin and thick film) influences strongly the functional features of the layers as well. The correlation between the indicated factors and gas-sensitive performance of the sensors has been established. Thus, doping $\mathrm{SnO}_{2}$ with $\mathrm{Fe}^{3+}$ ions leads to the sensor response decrease to most of gases, in particular $\mathrm{NO}_{2}$ and $\mathrm{C}_{2} \mathrm{H}_{5} \mathrm{OH}$, that is caused by the occurrence of separately 400 distributed $\mathrm{Fe}(\mathrm{III})$ ions within $\mathrm{SnO}_{2}$ matrix; no clusters of 401 amorphous $\mathrm{Fe}_{2} \mathrm{O}_{3}$ are present. Good performance of the sen- 402 sors is typical of the $\mathrm{Fe}_{2} \mathrm{O}_{3}-\mathrm{SnO}_{2}$ composites with $\mathrm{Fe}: \mathrm{Sn} \geq 403$ 1. Advanced oxide gas-sensitive materials were obtained 404 under the used conditions of synthesis and mode of ther- 405 mal treatment of the layers. The highly defective $\alpha-\mathrm{Fe}_{2} \mathrm{O}_{3} \quad 406$ phase provides suitable sensor conductivity and high sen- 407 sitivity. Besides, the occurrence of two types of adsorption 408 centres ( $\mathrm{Sn}(\mathrm{IV})$ and $\mathrm{Fe}(\mathrm{III})$ ), which possess different activ- 409 ity in both reduction-oxidation and acid-base reactions re- 410 sults in additional improvement of the sensor sensitivity to 411 ethanol vapours.

Certain distinctions were revealed in the behaviour of the 413 $\mathrm{Fe}_{2} \mathrm{O}_{3}-\mathrm{SnO}_{2}$ composites obtained either through the crys- 414 tallisation of amorphous $\mathrm{Fe}_{2} \mathrm{O}_{3}$ or as a result of thermally 415 induced transformation of $\gamma-\mathrm{Fe}_{2} \mathrm{O}_{3}$. The composites ob- 416 tained via $\mathrm{Fe}^{2+}$ precursors differ by slightly decreased re- 417 sponse and unsuitable $\Delta R_{\text {layer }} / \Delta C_{\text {gas }}$ ratio as compared to 418 the corresponding species prepared through the $\mathrm{Fe}^{3+}$ salt 419 hydrolysis.

\section{Acknowledgements}

This work has been supported by INTAS program (project 422 No. 2000-0066).

\section{References}

[1] P.G. Harrison, Chemistry of Tin, Chapman \& Hall, New York, 1989, Chapter 12, pp. 413-418.

425

[2] F.H. Chibirova, E.E. Gutman, Structural defects and gas-sensitive properties of some semiconductor metal oxides, Russ. J. Phys. Chem. 74 (9) (2000) 1555-1561.

[3] D. Orlik, M. Ivanovskaya, A. Gurlo, Properties of ceramic semiconductor sensors based on $\mathrm{SnO}_{2}-\mathrm{Sb}_{2} \mathrm{O}_{3}$, Russ. J. Anal. Chem. 52 (1) (1997) 69-73. the catalytic introduction procedure on the nano- $\mathrm{SnO}_{2}$ gas sensor 434 performances, Sens. Actuators B: Chem. 79 (2001) 98-106.

[5] M. Ivanovskaya, D. Kotsikau, G. Faglia, et al., Gas-sensitive prop- 436 erties of thin film heterostructures based on $\mathrm{Fe}_{2} \mathrm{O}_{3}-\mathrm{In}_{2} \mathrm{O}_{3}$ nanocom- 437 posites, Sens. Actuators B: Chem. 93 (2003) 422-430. 438

[6] N. Yamazoe, New approaches for improving semiconductor gas sen- 439 sors, Sens. Actuators B: Chem. 5 (1991) 7-19.

[7] O. Tan, W. Zhu, Q. Yan, et al., Size effect and gas sensing characteristics of nanocrystalline $x \mathrm{SnO}_{2}-(1-x) \alpha-\mathrm{Fe}_{2} \mathrm{O}_{3}$ ethanol sensors, Sens. Actuators B: Chem. 65 (2000) 361-365.

[8] P. Bonzi, L. Depero, F. Parmigiani, et al., Formation and structure of 444 tin-iron oxide thin film CO sensors, Mater. Res. Soc. 9 (5) (1994) 445 1250-1256.

[9] W. Chung, D. Lee, Characteristics of $\alpha-\mathrm{Fe}_{2} \mathrm{O}_{3}$ thick film gas sensors, 447 Thin Solid Films 200 (1991) 329-339.

[10] Sh.K. Shaikhutdinov, Y. Joseph, C. Kuhrs, et al., Faraday Discuss. 449 114 (1999) 363-380.

[11] M. Ivanovskaya, P. Bogdanov, G. Faglia, et al., The features of thin 45 film and ceramic sensors for the detection of $\mathrm{CO}$ and $\mathrm{NO}_{2}$, Sens. 452 Actuators B: Chem. 68 (2000) 344-350.

\section{(1)}

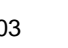
(a) . . (1)

\section{.} (a) (1) (n) (n) 
[12] P.G. Harrison, M.J. Willett, Tin oxide surfaces, J. Chem. Soc., Faraday Trans. 185 (8) (1989) 1921-1932.

[13] M. Ivanovskaya, G. Branitsky, D. Orlik, et al., Nature of paramagnetic centres in tin dioxide, Russ. J. Inorg. Chem. 37 (5) (1992) 1147 1152.

[14] F.J. Berry, O. Helgasson, A. Bohorques, Preparation and characterization of tin-doped $\alpha-\mathrm{FeOOH}$ (goethite), J. Mater. Sci. 10 (2000) $1643-1648$.

[15] F.J. Berry, C. Greaves, O. Helgasson, et al., Synthesis and characterisation of tin-doped iron oxides, J. Mater. Chem. 9 (1999) 223 226.

[16] J. Kappler, N. Barsan, U. Weimar, Structure and reactivity of iron oxide surfaces, in: Proceedings of the International Conference on Eurosensors XI, vols. 3B1-3B3, Warsaw, Poland, 21-24 September 1997, p. 1177.

[17] P. Bogdanov, M. Ivanovskaya, E. Comini, et al., Effect of nickel ions on sensitivity of $\operatorname{In}_{2} \mathrm{O}_{3}$ thin film sensors to $\mathrm{NO}_{2}$, Sens. Actuators B: Chem. 57 (1999) 153-158.

[18] M. Ivanovskaya, D. Kotsikau, D. Orlik, et al., About the possibility of metal oxide sensors application for environmental control, in: Proceedings of the International Workshop on New Developments on Sensors for Environmental Control, S. Cesarea Terme, Italy, 27-29 May 2002, p. 96.

[19] D. Kohl, Influence of water vapour on nanocrystalline $\mathrm{SnO}_{2}$ to monitor $\mathrm{CO}$ and $\mathrm{CH}_{4}$, Sens. Actuators B: Chem. 18 (1989) $71-$ 113.

[20] J. Livage, J.P. Jolivet, E. Tronc, Electronic properties of mixed valence oxide gels, J. Non-Cryst. Solids 121 (1990) 35-39.

[21] G. Golodets, Catalysis Mechanism, Part 1, Nauka, Novosibirsk, 1984, p. 142.

[22] M. Ivanovskaya, D. Kotsikau, G. Faglia, et al., Influence of chemical composition and structural factors of $\mathrm{Fe}_{2} \mathrm{O}_{3} / \mathrm{In}_{2} \mathrm{O}_{3}$ sensors on their selectivity and sensitivity to ethanol, Sens. Actuators B: Chem. 96 (2003) 498-503.

\section{Biographies}

Dzmitry Kotsikau graduated from the Belarus State University in 2001 with honours; in the same year he entered the post graduate courses simultaneously, he is working at the Scientific Research Institute for Physical and Chemical Problems of Belarus State University in the field of solid state chemistry and semiconductor gas sensors. His main scientific interests are $\mathrm{Fe}_{2} \mathrm{O}_{3}-\mathrm{In}_{2} \mathrm{O}_{3}$ and $\mathrm{Fe}_{2} \mathrm{O}_{3}-\mathrm{SnO}_{2}$ nanosized composites, their structural and gas-sensitive characterisation.

Maria Ivanovskaya received her degree in chemistry in 1980 from Belarus State University in the field of photochemistry. Since 1989 she has been working at the Scientific Research Institute of Physical and Chemical Problems (Belarus State University). Her main scientific interest is solid state chemistry in applications to catalysis and semiconductor gas sensors, structural features of nanosized oxides $\left(\mathrm{SnO}_{2}, \mathrm{MoO}_{3}, \mathrm{In}_{2} \mathrm{O}_{3}, \mathrm{Fe}_{2} \mathrm{O}_{3}\right)$ and oxide composites. She is co-author of more than 200 papers on the indicated topics.

Dmitry Orlik received his $\mathrm{PhD}$ degree in chemistry in 1990 from Belarus State University with a thesis on gas sensors and structural characterisation of oxide systems. Now he is occupying the research position in the Scientific Research Institute for Physical and Chemical Problems (Belarus State University). Now he is working in the field of solid state chemistry and semiconductor gas sensors.

Matteo Falasconi received an MS degree in physics with honours at 510 University of Pavia in 2000, defending a thesis on non-linear surface 511 optical properties of crystalline and porous silicon. From 2002 he is 512 member of the Sensor Laboratory at University of Brescia as PhD student 513 in materials engineering. He is involved in the study and characterization 514 of semiconducting metal oxide sensors collaborating to the development 515 of an electronic olfacting system.
489 